\title{
Acute Miliary Tuberculosis in Pregnancy After in Vitro Fertilization and Embryo Transfer: Report of Seven Cases and Systemic Review
}

\author{
Xiaoyan Gai \\ Peking University Third Hospital \\ Hongbin Chi \\ Peking University Third Hospital \\ Wenli Cao \\ Beijing Geriatric Hospital \\ Lin Zeng \\ Peking University Third Hospital \\ Lixue Chen \\ Peking University Third Hospital \\ Weixia Zhang \\ Peking University Third Hospital \\ Donghong Song \\ Peking University Third Hospital \\ Ying Wang \\ Peking University Third Hospital \\ Ping Liu \\ Peking University Third Hospital \\ Rong Li ( $\sim$ roseli001@sina.com) \\ Peking University Third Hospital \\ Yongchang Sun \\ Peking University Third Hospital
}

Research article

Keywords: Miliary tuberculosis, Infertility, In vitro fertilization, Embryo transfer

Posted Date: August 31st, 2020

DOI: https://doi.org/10.21203/rs.3.rs-64454/v1

License: (c) (i) This work is licensed under a Creative Commons Attribution 4.0 International License. Read Full License 


\section{Abstract}

\section{Background}

While miliary tuberculosis (TB) in pregnancy is rare after in vitro fertilization and embryo transfer (IVF-ET), it poses a serious threat to the health of pregnant women and their fetuses. The present study aimed to describe the clinical features of miliary TB and pregnancy outcomes of patients after IVF-ET.

\section{Methods}

Data of infertile patients who received IVF-ET at Peking University Third Hospital between January 2012 to December 2017 were retrospectively analyzed. Patients who developed miliary TB during pregnancy were identified, and clinical characteristics of miliary TB were described. The keywords "infertility," "in vitro fertilization and embryo transfer," and "tuberculosis" were used to search for articles published from 1980 to 2019 in PubMed, Medline, and EMBASE databases.

\section{Results}

Of 62,755 enrolled women, 7137 (11.4\%) showed signs of prior pulmonary TB on chest X-ray (CXR). Seven patients aged 28-35 years had miliary TB during pregnancy, with two patients complicated by TB meningitis. All of these patients presented with fever. Notably, old TB lesions were detected on CXR in six patients before IVF-ET; nevertheless, no anti-TB therapy was administered. Furthermore, salpingography revealed oviduct obstruction in all patients (7/7). Patients received anti-TB therapy following a diagnosis of miliary TB and were clinically cured. However, pregnancy was terminated due to spontaneous (4/7) and induced (3/7) abortion. Previous literature indicates that signs of prior TB on CXR and oviduct obstruction on laparoscopy are risk factors for TB reactivation during pregnancy, which displayed a trend for hematogenous dissemination.

\section{Conclusions}

TB reactivation, mostly as miliary TB and TB meningitis, is severe in pregnant women after IVF-ET and deleterious to pregnancy outcomes. The coexistence of primary infertility, untreated prior pulmonary TB, and fallopian tube obstruction is a risk factor for TB dissemination.

\section{Background}

Active tuberculosis (TB) is rare in pregnancy after in vitro fertilization and embryo transfer (IVF-ET) in infertile patients. However, with the increasing application of assisted reproductive technology, the incidence of TB in pregnancy has gradually increased, posing a serious threat to the health of pregnant women and fetuses [1, 2]. As clinical symptoms such as fever and cough are nonspecific and chest X-rays (CXR) during pregnancy are associated with the risk of radiation exposure, pulmonary TB in pregnancy is often under-diagnosed. There have been occasional case reports of TB with hematogenous dissemination and miliary TB and/or meningitis during pregnancy after IVF-ET, leading to abortion, fetal malformation, or increased risk of mortality [3, 4]. Therefore, correct and timely diagnosis and management of TB in pregnancy is important. Thus, this study aimed to describe the clinical features of miliary TB and its impact on pregnancy outcomes after IVF-ET. We retrospectively analyzed the data of patients who underwent IVF-ET and showed clinical signs of miliary TB during pregnancy between January 2012 and December 2017 at the reproductive center of our hospital. We also conducted a literature search for TB after IVF-ET and summarized clinical manifestations and pregnancy outcomes of these patients.

\section{Methods}

This was a retrospective study of patients who underwent IVF-ET for infertility between January 1, 2012, and December 31, 2017, at Peking University Third Hospital, a tertiary referral hospital in Beijing, China. Data on patients undergoing IVF-ET, including causes of infertility, serum hormone concentrations, the controlled ovarian hyperstimulation protocol, and CXR results, were recorded. CXR was routinely taken for each patient, and active TB cases were excluded before IVF-ET was started. A medical team was assigned to follow the pregnancy outcomes.

During the 6-year period, 62,755 patients, who were all HIV-negative, had received IVF-ET at our center, and among them, seven patients with active TB during pregnancy were identified. The diagnosis of active tuberculosis was in accordance with national guidelines [5]. The diagnosis of miliary TB was made based on the equality of the size, distribution, and density of miliary-like nodules bilaterally diffused on CXR or chest computed tomography (CT) scan [6, 7]. Baseline data, CXR, and laparoscopy results before IVF-ET were retrieved. A respiratory physician contacted the seven patients through the phone and reviewed the medical record. This study was approved by the Ethics Committee of Peking University Third Hospital (batch number: (2019)327-02). The retrospective nature of the study resulted in a waiver regarding the signing of the informed consent form 


\section{IVF-ET protocol}

IVF-ET was performed as previously described [8]. In brief, controlled ovarian hyperstimulation was achieved, oocytes were fertilized, and then embryo transfers were performed [8]. For the seven patients who developed TB during pregnancy, one had undergone a frozen cycle transfer, while the remaining six had undergone fresh cycle transfer. After embryo transfer, $60 \mathrm{mg}$ of progesterone was injected intramuscularly for 14 days. Blood human chorionic gonadotropin concentration was monitored at 2 weeks after transplantation, and the status of the embryo sac was examined by ultrasonography at 4 weeks after transplantation.

\section{Literature retrieval and analysis ofpatients with TB during pregnancy after IVF-ET}

We used the keywords "infertility," "in vitro fertilization and embryo transfer," and "tuberculosis" to search for articles published from 1980 to 2019 in PubMed, MEDLINE, and Wanfang databases and summarized the clinical manifestations and pregnancy outcomes of the identified cases.

\section{Results}

\section{Patient baseline data}

Between January 1, 2012, and December 31, 2017, a total of 62,755 women (mean age, 33.1 years; range, 20-50 years) who had been referred to the reproductive center were enrolled in this study. Based on the CXR results before IVF-ET, $11.4 \%$ of patients (7137/62,755) were found to exhibit signs of prior pulmonary TB. From the total population, seven patients with acute miliary TB during pregnancy were identified.

\section{Baseline data of the seven patients with active TB during pregnancy}

Among the seven cases, four occurred in 2012, two in 2016, and one in 2017. These pregnant women were between 28 and 34 years of age, and the duration of infertility ranged $1-12$ years. The body mass index was $20.1-27.3 \mathrm{~kg} / \mathrm{m}^{2}$. All seven patients had primary infertility due to unilateral or bilateral oviduct obstruction, assessed by salpingography; four patients also underwent laparoscopy, with manifestations of tubal obstruction and adhesion consistent with TB, but the pathology failed to reveal features of TB. One patient had suffered from TB at the age of 16 , and the local hospital administered anti-TB therapies for over 6 months at that time. The other six patients had no clinical history of TB and had not received anti-TB treatment. Among the seven patients, six showed signs of old pulmonary TB lesions on CXR before IVF-ET. Tuberculin skin test (TST) was performed in three patients before IVF-ET, with induration diameters of 10-20 mm, thus confirming them as positive (++) cases. However, this test was not performed in the other four patients. None had active TB before IVF-ET, and IVF-ET was performed as scheduled (Table 1). 
Table 1

Baseline characteristics of the seven cases of miliary TB

\begin{tabular}{|c|c|c|c|c|c|c|c|c|c|}
\hline Case & $\begin{array}{l}\text { Type of } \\
\text { infertility }\end{array}$ & $\begin{array}{l}\text { Infertility } \\
\text { duration } \\
\text { (years) }\end{array}$ & $\begin{array}{l}\text { Infertility } \\
\text { factor }\end{array}$ & $\begin{array}{l}\text { Past } \\
\text { history }\end{array}$ & $\begin{array}{l}\text { CXR before } \\
\text { IVF-ET }\end{array}$ & Salpingography & Laparoscopy & Pathology & ESR \\
\hline 1 & $\begin{array}{l}\text { Primary } \\
\text { infertility }\end{array}$ & 12 & $\begin{array}{l}\text { Fallopian } \\
\text { tubal } \\
\text { ovulation }\end{array}$ & $\begin{array}{l}\text { Denial of } \\
\text { TB history }\end{array}$ & $\begin{array}{l}\text { Fibrotic } \\
\text { scars in } \\
\text { upper left } \\
\text { lung }\end{array}$ & $\begin{array}{l}\text { Bilateral } \\
\text { oviduct } \\
\text { obstruction }\end{array}$ & $\begin{array}{l}\text { Extensive pelvic } \\
\text { adhesion, bilateral } \\
\text { ovarian adhesion. } \\
\text { Yellow hard } \\
\text { neoplasm could be } \\
\text { seen at the } \\
\text { umbrella end of } \\
\text { the right oviduct } \\
\text { and the mesentery; } \\
\text { Pelvic adhesiolysis } \\
\text { and } \\
\text { salpingostomy; }\end{array}$ & $\begin{array}{l}\text { Peritoneal } \\
\text { fibrous nodules } \\
\text { complicated by } \\
\text { hyaline } \\
\text { degeneration }\end{array}$ & 8 \\
\hline 2 & $\begin{array}{l}\text { Primary } \\
\text { infertility }\end{array}$ & 4 & $\begin{array}{l}\text { Fallopian } \\
\text { tubal } \\
\text { ovulation }\end{array}$ & $\begin{array}{l}\text { Denial of } \\
\text { TB history }\end{array}$ & $\begin{array}{l}\text { Left pleural } \\
\text { thickening } \\
\text { and } \\
\text { adhesion }\end{array}$ & $\begin{array}{l}\text { Bilateral } \\
\text { oviduct } \\
\text { umbrella end } \\
\text { adhesion }\end{array}$ & $\begin{array}{l}\text { Bilateral oviduct } \\
\text { obstruction, after } \\
\text { laparoscopic } \\
\text { recanalization }\end{array}$ & Endometritis & 6 \\
\hline 3 & $\begin{array}{l}\text { Primary } \\
\text { infertility }\end{array}$ & 9 & $\begin{array}{l}\text { Fallopian } \\
\text { tubal } \\
\text { ovulation }\end{array}$ & $\begin{array}{l}\text { Denial of } \\
\text { TB history }\end{array}$ & $\begin{array}{l}\text { Fibrotic } \\
\text { scars in } \\
\text { upper right } \\
\text { lung }\end{array}$ & $\begin{array}{l}\text { Bilateral } \\
\text { oviduct } \\
\text { obstruction }\end{array}$ & NA & NA & 6 \\
\hline 4 & $\begin{array}{l}\text { Primary } \\
\text { infertility }\end{array}$ & 7 & $\begin{array}{l}\text { Fallopian } \\
\text { tubal } \\
\text { ovulation }\end{array}$ & $\begin{array}{l}\text { Denial of } \\
\text { TB history }\end{array}$ & $\begin{array}{l}\text { Fibrotic } \\
\text { scars in } \\
\text { upper left } \\
\text { lung }\end{array}$ & $\begin{array}{l}\text { Bilateral } \\
\text { oviduct } \\
\text { obstruction }\end{array}$ & $\begin{array}{l}\text { Bilateral oviduct } \\
\text { obstruction; } \\
\text { Bilateral } \\
\text { salpingoplasty }\end{array}$ & $\begin{array}{l}\text { manifestation } \\
\text { of } \\
\text { secretive phase }\end{array}$ & 6 \\
\hline 5 & $\begin{array}{l}\text { Primary } \\
\text { infertility }\end{array}$ & 5 & $\begin{array}{l}\text { Fallopian } \\
\text { tubal } \\
\text { ovulation; } \\
\text { PCOS }\end{array}$ & $\begin{array}{l}\text { Denial of } \\
\text { TB history }\end{array}$ & $\begin{array}{l}\text { No } \\
\text { abnormality }\end{array}$ & $\begin{array}{l}\text { Left oviduct } \\
\text { obstruction; } \\
\text { Right oviduct } \\
\text { unsmooth; }\end{array}$ & $\begin{array}{l}\text { Bilateral oviduct } \\
\text { obstruction }\end{array}$ & Endometritis & 5 \\
\hline 6 & $\begin{array}{l}\text { Primary } \\
\text { infertility }\end{array}$ & 1 & $\begin{array}{l}\text { Fallopian } \\
\text { tubal } \\
\text { ovulation }\end{array}$ & $\begin{array}{l}\text { Denial of } \\
\text { TB history; } \\
\text { One IVF- } \\
\text { ET failed } \\
\text { history; }\end{array}$ & $\begin{array}{l}\text { Left pleural } \\
\text { thickening }\end{array}$ & $\begin{array}{l}\text { Left oviduct } \\
\text { obstruction; } \\
\text { Right oviduct } \\
\text { unsmooth; }\end{array}$ & NA & NA & 5 \\
\hline 7 & $\begin{array}{l}\text { Primary } \\
\text { infertility }\end{array}$ & 3 & $\begin{array}{l}\text { Fallopian } \\
\text { tubal } \\
\text { ovulation }\end{array}$ & $\begin{array}{l}\text { Pulmonary } \\
\text { TB at the } \\
\text { age of } 16\end{array}$ & $\begin{array}{l}\text { Fibrous } \\
\text { scars in the } \\
\text { upper right } \\
\text { lung; Left } \\
\text { pleural } \\
\text { thickening } \\
\text { and } \\
\text { adhesion }\end{array}$ & $\begin{array}{l}\text { Bilateral } \\
\text { oviduct } \\
\text { obstruction }\end{array}$ & NA & NA & 6 \\
\hline
\end{tabular}

One patient underwent frozen ET and had a singleton pregnancy. The remaining six patients underwent fresh ET: three had twin pregnancies and three had singleton pregnancies.

\section{Clinical manifestations and diagnosis of active TB during pregnancy}

All seven patients had fever at 7-14 weeks of pregnancy. Among them, six had moderate-to-high fever, with the highest body temperatures recorded at $38.5-40^{\circ} \mathrm{C}$, whereas one had low-grade fever $\left(37.5^{\circ} \mathrm{C}\right)$. All seven patients had mild cough and a small amount of sputum with $(1 / 7)$ or without blood (6/7). CXR and CT scans were performed on all seven patients, which showed diffuse miliary nodules in both lungs, consistent with acute miliary TB (Fig. 1). Two patients with significant headache were diagnosed with TB meningitis using lumbar puncture (Table 2). 
Table 2

Clinical manifestations and pregnancy outcomes of the seven cases of miliary TB during pregnancy

\begin{tabular}{|c|c|c|c|c|c|c|c|c|c|c|}
\hline Case & $\begin{array}{l}\text { IVF-ET } \\
\text { cycle } \\
\text { type }\end{array}$ & $\begin{array}{l}\text { IVF-ET } \\
\text { outcomes }\end{array}$ & $\begin{array}{l}\text { Vaginal } \\
\text { bleeding }\end{array}$ & $\begin{array}{l}\text { Gestational } \\
\text { weeks with } \\
\text { bleeding } \\
(w)\end{array}$ & Fever & $\begin{array}{l}\text { Gestational } \\
\text { weeks with } \\
\text { fever (w) }\end{array}$ & $\begin{array}{l}\text { TST } \\
\text { after } \\
\text { fever } \\
\text { onset }\end{array}$ & $\begin{array}{l}\text { IGRA } \\
\text { after } \\
\text { fever } \\
\text { onset }\end{array}$ & $\begin{array}{l}\text { Pregnancy } \\
\text { outcomes }\end{array}$ & Follow-up \\
\hline 1 & $\begin{array}{l}\text { Fresh } \\
\text { ET }\end{array}$ & Singleton & + & 7 & + & 12 & NA & NA & $\begin{array}{l}\text { Spontaneous } \\
\text { abortion }\end{array}$ & $\begin{array}{l}\text { Received ET again and } \\
\text { gave birth } 3 \text { years later } \\
\text { after TB. }\end{array}$ \\
\hline 2 & $\begin{array}{l}\text { Fresh } \\
\text { ET }\end{array}$ & Twin & + & 17 & + & 14 & NA & + & $\begin{array}{l}\text { Spontaneous } \\
\text { abortion }\end{array}$ & $\begin{array}{l}\text { Underwent two rounds } \\
\text { of ET } 3 \text { years later, yet } \\
\text { both failed. }\end{array}$ \\
\hline 3 & $\begin{array}{l}\text { Fresh } \\
\text { ET }\end{array}$ & Singleton & - & - & + & 9 & NA & + & $\begin{array}{l}\text { Induced } \\
\text { abortion }\end{array}$ & No pregnancy since. \\
\hline 4 & $\begin{array}{l}\text { Fresh } \\
\text { ET }\end{array}$ & Twin & - & - & + & 7 & NA & + & $\begin{array}{l}\text { Induced } \\
\text { abortion }\end{array}$ & $\begin{array}{l}\text { Underwent ET } 3 \text { years } \\
\text { later yet failed. No } \\
\text { pregnancy since. }\end{array}$ \\
\hline 5 & $\begin{array}{l}\text { Frozen } \\
\text { ET }\end{array}$ & Singleton & + & 8 & + & 10 & +++ & + & $\begin{array}{l}\text { Spontaneous } \\
\text { abortion }\end{array}$ & $\begin{array}{l}\text { No pregnancy after } \\
\text { three rounds of ET. }\end{array}$ \\
\hline 6 & $\begin{array}{l}\text { Fresh } \\
\text { ET }\end{array}$ & Twin & + & 14 & + & 12 & NA & + & $\begin{array}{l}\text { Spontaneous } \\
\text { abortion }\end{array}$ & $\begin{array}{l}\text { Underwent fresh ET } \\
\text { and two rounds of } \\
\text { frozen ET } 5 \text { years later, } \\
\text { yet all failed. No } \\
\text { pregnancy since. }\end{array}$ \\
\hline 7 & $\begin{array}{l}\text { Fresh } \\
\text { ET }\end{array}$ & Singleton & + & 8 & + & 9 & NA & NA & $\begin{array}{l}\text { Induced } \\
\text { abortion }\end{array}$ & $\begin{array}{l}\text { Experienced one failed } \\
\text { frozen ET } 6 \text { years later; } \\
\text { got pregnant and gave } \\
\text { birth after another ET } \\
7 \text { years later. }\end{array}$ \\
\hline
\end{tabular}

Five patients underwent an interferon gamma release assay (IGRA) test after fever onset and showed positive results. One patient underwent a TST, which was positive (+++).

\section{Outcomes of TB and pregnancy outcomes of the seven patients}

After the diagnosis of TB, four patients had spontaneous abortion, whereas three patients underwent induced abortion (Table 2). All seven patients recovered after anti-TB therapy. At follow-up, two patients achieved pregnancy after second IVF-ET.

\section{Literature review}

We searched the published literature and summarized 37 cases of TB during pregnancy after IVF-ET [3, 9-17], as shown in Table 3. In 1988, Addis et al. reported the first case of miliary TB in pregnancy after IVF-ET [3]. Since then, there have been occasional case reports of this disease, mostly in developing countries $[10-14,17]$. 
Table 3

Summary of reported cases of TB during pregnancy after IVF-ET

\begin{tabular}{|c|c|c|c|c|c|c|c|c|c|}
\hline Cases & $\begin{array}{l}\text { Age } \\
\text { (years) }\end{array}$ & $\begin{array}{l}\text { Onset } \\
\text { time } \\
\text { (week) }\end{array}$ & TB history & $\begin{array}{l}\text { Clinical } \\
\text { manifestations }\end{array}$ & Diagnosis & $\begin{array}{l}\text { Pregnancy } \\
\text { outcomes } \\
\text { for } \\
\text { pregnant } \\
\text { women }\end{array}$ & $\begin{array}{l}\text { Outcomes } \\
\text { for fetus }\end{array}$ & Country & Reference \\
\hline 1 & 33 & 10 & Denial of TB history & $\begin{array}{l}\text { Fever, cough, } \\
\text { shortness of } \\
\text { breath }\end{array}$ & $\begin{array}{l}\text { Miliary TB } \\
(1 / 1)\end{array}$ & Cured & $\begin{array}{l}\text { Spontaneous } \\
\text { abortion }\end{array}$ & U.K. & $\begin{array}{l}\text { Addis et al. } \\
\text { [3] }\end{array}$ \\
\hline 5 & $25-33$ & $5-9$ & $\begin{array}{l}\text { Denial of TB history; } \\
\text { Laparoscopy } \\
\text { showed bilateral } \\
\text { oviduct obstruction } \\
(5 / 5)\end{array}$ & Fever $(5 / 5)$ & $\begin{array}{l}\text { Miliary TB } \\
(5 / 5)\end{array}$ & Cured & $\begin{array}{l}\text { Spontaneous } \\
\text { abortion } \\
(5 / 5)\end{array}$ & China & $\begin{array}{l}\text { Wei et al. } \\
\text { [9] }\end{array}$ \\
\hline 4 & NA & $5-15$ & Denial of TB history & Fever (4/4) & $\begin{array}{l}\text { Miliary TB } \\
(4 / 4) ; \\
\text { ARDS } \\
(1 / 4)\end{array}$ & $\begin{array}{l}\text { Died }(1 / 4) ; \\
\text { Cured } \\
(3 / 4)\end{array}$ & $\begin{array}{l}\text { Spontaneous } \\
\text { abortion } \\
(4 / 4)\end{array}$ & China & $\begin{array}{l}\text { Wei et al. } \\
\text { [10] }\end{array}$ \\
\hline 1 & 29 & 11 & $\begin{array}{l}\text { Denial of TB history; } \\
\text { laparoscopy } \\
\text { showed bilateral } \\
\text { oviduct obstruction }\end{array}$ & $\begin{array}{l}\text { Fever, } \\
\text { shortness of } \\
\text { breath }\end{array}$ & $\begin{array}{l}\text { Miliary TB } \\
(1 / 1)\end{array}$ & Cured & $\begin{array}{l}\text { Spontaneous } \\
\text { abortion }\end{array}$ & China & $\begin{array}{l}\text { Liu et al. } \\
\text { [11] }\end{array}$ \\
\hline 6 & $27-32$ & $6-9$ & $\begin{array}{l}\text { One case had a } \\
\text { history of } \\
\text { tuberculous } \\
\text { pleuritis, and } 1 \text { case } \\
\text { had a history of } \\
\text { pelvic TB }\end{array}$ & $\begin{array}{l}\text { Fever }(6 / 6) \text {, } \\
\text { slight cough } \\
\text { and } \\
\text { expectoration } \\
(6 / 6)\end{array}$ & $\begin{array}{l}\text { Miliary TB } \\
(6 / 6)\end{array}$ & Cured & $\begin{array}{l}\text { Spontaneous } \\
\text { abortion } \\
(5 / 6) ; \\
\text { induced } \\
\text { abortion } \\
(1 / 6)\end{array}$ & China & $\begin{array}{l}\text { Gao et al. } \\
\text { [12] }\end{array}$ \\
\hline 11 & $26-36$ & $6-14$ & Denial of TB history & Fever $(11 / 11)$ & $\begin{array}{l}\text { Miliary TB } \\
(11 / 11) \\
\text { TB } \\
\text { meningitis } \\
(4 / 11)\end{array}$ & Cured & $\begin{array}{l}\text { Spontaneous } \\
\text { abortion } \\
(8 / 11) \\
\text { induced } \\
\text { abortion } \\
(3 / 11)\end{array}$ & China & $\begin{array}{l}\text { Jin et al. } \\
\text { [13] }\end{array}$ \\
\hline 6 & $29-39$ & $\begin{array}{l}5-16 \\
(5 / 6) \\
26 \\
(1 / 6)\end{array}$ & $\begin{array}{l}\text { One case had a } \\
\text { history of TB, one } \\
\text { case had no history } \\
\text { of TB, but chest } \\
\text { radiograph showed } \\
\text { sclerotic } \\
\text { calcification in the } \\
\text { lung(s), and the } \\
\text { other } 4 \text { cases had } \\
\text { no manifestation of } \\
\text { TB }\end{array}$ & $\begin{array}{l}\text { Fever, cough, } \\
\text { shortness of } \\
\text { breath }(6 / 6) ; \\
\text { Headache } \\
(1 / 6)\end{array}$ & $\begin{array}{l}\text { Miliary TB } \\
(6 / 6) ; \mathrm{TB} \\
\text { meningitis } \\
(1 / 6)\end{array}$ & Cured & $\begin{array}{l}\text { Spontaneous } \\
\text { abortion } \\
(3 / 6) ; \\
\text { induced } \\
\text { abortion } \\
(3 / 6)\end{array}$ & China & $\begin{array}{l}\text { Ye et al. } \\
{[14]}\end{array}$ \\
\hline 1 & 38 & 14 & $\begin{array}{l}\text { Denial of TB history, } \\
\text { and laparoscopy } \\
\text { showed bilateral } \\
\text { oviduct obstruction }\end{array}$ & Fever, cough & $\begin{array}{l}\text { Miliary TB } \\
\text { with TB } \\
\text { meningitis } \\
(1 / 1)\end{array}$ & Cured & $\begin{array}{l}\text { Spontaneous } \\
\text { abortion }\end{array}$ & Israel & $\begin{array}{l}\text { Gull et al. } \\
\text { [15] }\end{array}$ \\
\hline 1 & NA & 8 & $\begin{array}{l}\text { Denial of TB history; } \\
\text { Laparoscopy } \\
\text { showed bilateral } \\
\text { oviduct obstruction }\end{array}$ & Fever, cough & $\begin{array}{l}\text { Miliary TB } \\
(1 / 1)\end{array}$ & Cured & $\begin{array}{l}\text { Spontaneous } \\
\text { abortion }\end{array}$ & Belgium & $\begin{array}{l}\text { Jacquemyn } \\
\text { et al. [16] }\end{array}$ \\
\hline 1 & 31 & 8 & $\begin{array}{l}\text { Denial of TB history; } \\
\text { Laparoscopy } \\
\text { showed bilateral } \\
\text { oviduct obstruction }\end{array}$ & Fever, cough & $\begin{array}{l}\text { Miliary TB } \\
(1 / 1)\end{array}$ & Cured & $\begin{array}{l}\text { Premature } \\
\text { delivery }\end{array}$ & China & $\begin{array}{l}\text { Fan XL } \\
\text { et al. [17] }\end{array}$ \\
\hline
\end{tabular}

\section{Discussion}

In this retrospective study, we examined seven cases of active TB during pregnancy from 62,755 cases of IVF-ET carried out at our hospital. All of these seven cases were diagnosed with acute miliary TB, with two cases complicated by TB meningitis. Of note, signs of prior TB on CXR in 
our study population were detected in $11.4 \%$ of patients $(7,137 / 62,755)$, and six of the seven patients with acute miliary TB had prior TB signs identified on CXR before IVF-ET.

On the basis of our case presentations and characterizations as well as the literature review, TB in pregnancy after IVF-ET mostly occurred during the first 8-12 weeks of pregnancy. Fever was the main symptom, and the time interval from fever onset to definitive diagnosis was 2-4 weeks or more. An important finding of our study was that TB in pregnancy after IVF-ET was prone to hematogenous dissemination, which is the most serious condition of TB [3,9-17]. TB dissemination may be related to latent infection, IVF-ET intervention, and immune dysregulation in pregnancy. Studies have shown that estrogen, progesterone, and human chorionic gonadotropin have a direct inhibitory effect on T-cells [18, 19]. High estrogen levels are conducive to the proliferation of Mycobacterium tuberculosis. Increased vascular permeability after pregnancy may also facilitate bacterial spread throughout the body, resulting in hematogenous dissemination [20]. The prognosis of miliary TB during pregnancy after IVF-ET was poor and may have caused the spontaneous abortion or may have resulted in premature delivery. More seriously, respiratory failure and even acute respiratory distress syndrome might occur in pregnant women [9]. Furthermore, fetuses might suffer from intrauterine growth retardation or be stillborn due to hypoxia or they might be infected through hematogenous dissemination or absorption of contaminated amniotic fluid [4]. Moreover, those with miliary TB during pregnancy were less likely to achieve pregnancy, even with IVF-ET.

Identifying patients at high risk of TB activation should be an important evaluation before IVF-ET, especially in regions with a high TB burden. From our observation, we speculate that the coexistence of primary infertility, untreated prior pulmonary TB, and fallopian tube obstruction may be a risk factor for active TB during an IVF-ET pregnancy. Signs of fibrotic scarring, calcified nodules, and/or pleural thickening on CXR indicate previous infection with $M$. tuberculosis [21-23]. In our series, among the 7137 patients who had old TB lesions on CXR, six developed miliary TB during pregnancy. Liu et al. reported a similar case in which untreated prior pulmonary TB developed into miliary TB during pregnancy [11]. Genital TB (GTB) is a form of extrapulmonary TB and a major cause of primary infertility among women in TB-endemic countries [24], with a prevalence rate of $28.4 \%$ in our hospital, as observed in previous studies [25, 26]. GTB may cause fallopian tube obstruction, reduced endometrial receptivity, and ovarian dysfunction, leading to infertility. However, manifestations of GTB are nonspecific, and confirmation of diagnosis relies on invasive procedures. Our seven patients showed unilateral or bilateral oviduct obstruction, which suggested chronic infections such as GTB.

Clinical diagnosis of TB in pregnant women is often delayed, largely because of the concern about radiation exposure. The IGRA is an important diagnostic method for detecting active TB and is safe for use in pregnancy [27-30]. Both the IGRA and TST have a high consistency of 77.3$88.0 \%$ [29]. The IGRA has a high sensitivity of $100 \%$ and a moderate specificity of $80.0 \%$ for detecting active TB during pregnancy [30], which is not affected by previous vaccination with Bacillus Calmette-Guérin. However, it remains unclear whether the IGRA and/or TST is required to assess latent TB infections before IVF-ET and whether preventive anti-TB therapy can improve the pregnancy outcomes of infertile women with latent TB or signs of prior pulmonary TB.

Our study has some limitations. First, this was a single-center study; however, as the largest reproductive center in China, we perform more than 10,000 cycles of IVF-ET annually on women from all over the country. Therefore, the population in this study was representative. Second, we inquired whether active TB had occurred during pregnancy through telephone follow-up of patients. This, however, could not rule out the possibility of missed diagnosis of TB during pregnancy.

\section{Conclusions}

Acute miliary TB rarely occurs in pregnant women after IVF-ET, especially in those with signs of prior pulmonary TB on CXR. The coexistence of primary infertility, untreated prior pulmonary $\mathrm{TB}$, and fallopian tube obstruction is a high risk factor for TB dissemination. Patients with miliary TB had poor pregnancy outcomes; therefore, clinicians should be aware of the signs of TB before administering a course of IVF-ET treatment to ensure the health of the patient and for successful outcome of a subsequent pregnancy. Prospective studies are needed to determine the rate of and risk factors for reactive TB in infertile patients with prior pulmonary TB after IVF-ET and whether anti-TB therapy is beneficial for pregnancy outcomes is these patients.

\section{Abbreviations}

CT: Computed tomography

CXR: Chest X-ray

GTB: Genital TB

IGRA: Interferon gamma release assay

IVF-ET: In vitro fertilization and embryo transfer 
TB: Tuberculosis

TST: Tuberculin skin test

\section{Declarations}

\section{Ethics approval and consent to participate}

This study was approved by the Ethics Committee of Peking University Third Hospital (batch number: (2019)327-02). The retrospective nature of the study resulted in a waiver regarding the signing of the informed consent form.

\section{Consent for publication}

Not applicable.

\section{Availability of data and materials}

The datasets used and/or analyzed during the current study are available from the corresponding author on reasonable request.

\section{Competing interests}

The authors declare that they have no competing interests.

\section{Funding}

This research was funded by the National Natural Science Foundation [No. 81400041] [No. 81871212] and the National Natural Science Foundation of China Youth Fund Project [No. 81400038]. The sponsors of the study had no role in study design, data collection, data analysis, data interpretation, or writing of the report. The corresponding author confirms that she had full access to all data in the study and had the final responsibility for the decision to submit for publication.

\section{Authors' contributions}

$\mathrm{RL}$ and $\mathrm{YS}$ jointly conceived and directed this work, and RL is the leading corresponding author. XG, HC, and WC had full access to all data in the study and take responsibility for the integrity of the data and the accuracy of data analysis. XG, HC, WC, LZ, LC, WZ, DS, YW, and PL participated in the acquisition, analysis, or interpretation of the data. XG and $\mathrm{HC}$ wrote the report. YS and RL were involved in manuscript editing. The final version has been reviewed and approved by all authors.

\section{Acknowledgments}

Not applicable.

\section{References}

1. Sugarman J, Colvin C, Moran AC, Oxlade O. Tuberculosis in pregnancy: an estimate of the global burden of disease. Lancet Glob Health. 2014;2:e710-6.

2. Sobhy S, Babiker Z, Zamora J, Khan KS, Kunst H. Maternal and perinatal mortality and morbidity associated with tuberculosis in pregnancy and the postpartum period: a systematic review and meta-analysis. BJOG. 2017;124:727-33.

3. Addis GM, Anthony GS, d'A Semple P, Miller AW. Miliary tuberculosis in an in-vitro fertilization pregnancy: a case report. Eur J Obstet Gynecol Reprod Biol. 1988;27:351-3.

4. Samedi V, Field SK, Al Awad E, Ratcliffe G, Yusuf K. Congenital tuberculosis in an extremely preterm infant conceived after in vitro fertilization: case report. BMC Pregnancy Childbirth. 2017;17:66.

5. Diseases Prevention and Control Department of China Health and Family Planning Commission. Guidelines for implementing the National Tuberculosis Control Program in China. Beijing: Peking Union Medical College Press; 2008. 
6. Ray S, Talukdar A, Kundu S, Khanra D, Sonthalia N. Diagnosis and management of miliary tuberculosis: current state and future perspectives. Ther Clin Risk Manag. 2013;9:9-26.

7. Deng W, Yu M, Ma H, Hu LA, Chen G, Wang Y, et al. Predictors and outcome of patients with acute respiratory distress syndrome caused by miliary tuberculosis: a retrospective study in Chongqing, China. BMC Infect Dis. 2012;12:121.

8. Wang H, Gao H, Chi H, Zeng L, Xiao W, Wang Y, et al. Effect of levothyroxine on miscarriage among women with normal thyroid function and thyroid autoimmunity undergoing in vitro fertilization and embryo transfer: a randomized clinical trial. JAMA. 2017;318:2190-8.

9. Wei Y, Wen E, Zhao YY, Wang LN, Qiao J. In vitro fertilization and embryo transplantation pregnancy complicated by acute miliary tuberculosis in five cases. Chin J Perinat Med. 2010;13:324-6. [In Chinese].

10. Wei Y, Zhao YY, Wang YQ. The clinic analysis of four cases of pregnancy of women with miliary tuberculosis after in vitro fertilization and embryo transfer. Int J Gynecol Obstet. 2009;107:545.

11. Hongbo L, Li Z. Miliary tuberculosis after in vitro fertilization and embryo transplantation. Afr Health Sci. 2015;15:701-4.

12. Gao HJ, Hu YJ, Zhu YM, Huang HF. Retrospective analysis of 6 cases of miliary tuberculosis in pregnant women after in vitro fertilization and embryo transplantation. Chin J Tuberc Respir Dis. 2007;30:848-50. [In Chinese with English abstract].

13. Jin C, Mi Z, Sun LF. Clinical characteristics of pulmonary tuberculosis in pregnant women after in vitro fertilization embryo transfer. Chin J Clin Infect Dis. 2014;7:137-9. [In Chinese with English abstract].

14. Ye R, Wang C, Zhao L, Wu X, Gao Y, Liu H. Characteristics of miliary tuberculosis in pregnant women after in vitro fertilisation and embryo transplantation. Int J Tuberc Lung Dis. 2019;23:136-9.

15. Gull I, Peyser MR, Yaron Y, Jaffa AJ, Amit A, Lessing JB. The effect of an in-vitro fertilization pregnancy on a woman with genital tuberculosis. Hum Reprod. 1995;10:3052-4.

16. Jacquemyn Y, Van Casteren C, Luijks M, Colpaert C. Disseminated tuberculosis in pregnancy unknown to doctors in Western Europe case presentation: 'part of the routine study in infertility'. BMJ Case Rep. 2012; 2012:bcr2012006227.

17. Fan XL, Chen ZJ, Li CY, Ma L. Analysis of a case of miliary tuberculosis in both lungs and premature delivery after in vitro fertilization and embryo transplantation pregnancy. Chin J Obstet Gynecol. 2003;38:637-8. [In Chinese].

18. Aghaeepour N, Ganio EA, Mcilwain D, Tsai AS, Tingle M, Van Gassen S, et al. An immune clock of human pregnancy. Sci Immunol. 2017;2:eaan2946.

19. Saito S, Nakashima A, Shima T, Ito M. Th1/Th2/Th17 and regulatory T-cell paradigm in pregnancy. Am J Reprod Immunol. 2010;63:601-10.

20. Yu N, Yang J, Guo Y, Fang J, Yin T, Luo J, et al. Intrauterine administration of peripheral blood mononuclear cells (PBMCs) improves endometrial receptivity in mice with embryonic implantation dysfunction. Am J Reprod Immunol. 2014;71:24-33.

21. Uzorka JW, Kroft LJM, Bakker JA, van Zwet EW, Huisman E, Prins C, et al. Abnormalities suggestive of latent tuberculosis infection on chest radiography; how specific are they? J Clin Tuberc Other Mycobact Dis. 2019;15:100089.

22. Uzorka JW, Wallinga J, Kroft LJM, Ottenhoff THM, Arend SM. Radiological signs of latent tuberculosis on chest radiography: a systematic review and meta-analysis. Open Forum Infect Dis. 2019;6:ofz313.

23. Nachiappan AC, Rahbar K, Shi X, Guy ES, Barbosa EJM Jr, Shroff GS, et al. Pulmonary tuberculosis: role of radiology in diagnosis and management. Radiographics. 2017;37:52-72.

24. Bhanothu V, Theophilus JP, Reddy PK, Rozati R. Occurrence of female genital tuberculosis among infertile women: a study from a tertiary maternal health care research centre in South India. Eur J Clin Microbiol Infect Dis. 2014;33:1937-49.

25. Zhang LZ, Wei ZX, Liu P. Factors affecting the clinical pregnancy rate in an in vitro fertilization and embryo transfer program. Chin $\mathrm{J}$ Obstet Gynecol. 1998;33:727-30. [In Chinese with English abstract].

26. Li MM, Li R. Progress in diagnosis and treatment of female genital tuberculosis induces infertility. Chin J Obstet Gynecol. 2015;50:954-6. [In Chinese].

27. Gupta RK, Kunst H, Lipman M, Noursadeghi M, Jackson C, Southern J, et al. Evaluation of QuantiFERON-TB Gold Plus for predicting incident tuberculosis among recent contacts: a prospective cohort study. Ann Am Thorac Soc. 2020;17:646-50.

28. Abubakar I, Drobniewski F, Southern J, Sitch AJ, Jackson C, Lipman M, et al. Prognostic value of interferon-g release assays and tuberculin skin test in predicting the development of active tuberculosis (UK PREDICT TB): a prospective cohort study. Lancet Infect Dis.

2018;18:1077-87.

29. Lighter-Fisher J, Surette AM. Performance of an interferon-gamma release assay to diagnose latent tuberculosis infection during pregnancy. Obstet Gynecol. 2012;119:1088-95.

30. Chen Q, Guo X, Wang X, Wang M. T-SPOT.TB in detection of active tuberculosis during pregnancy: a retrospective study in China. Med Sci Monit. 2016;22:57-60.

\section{Figures}

Page 9/10 


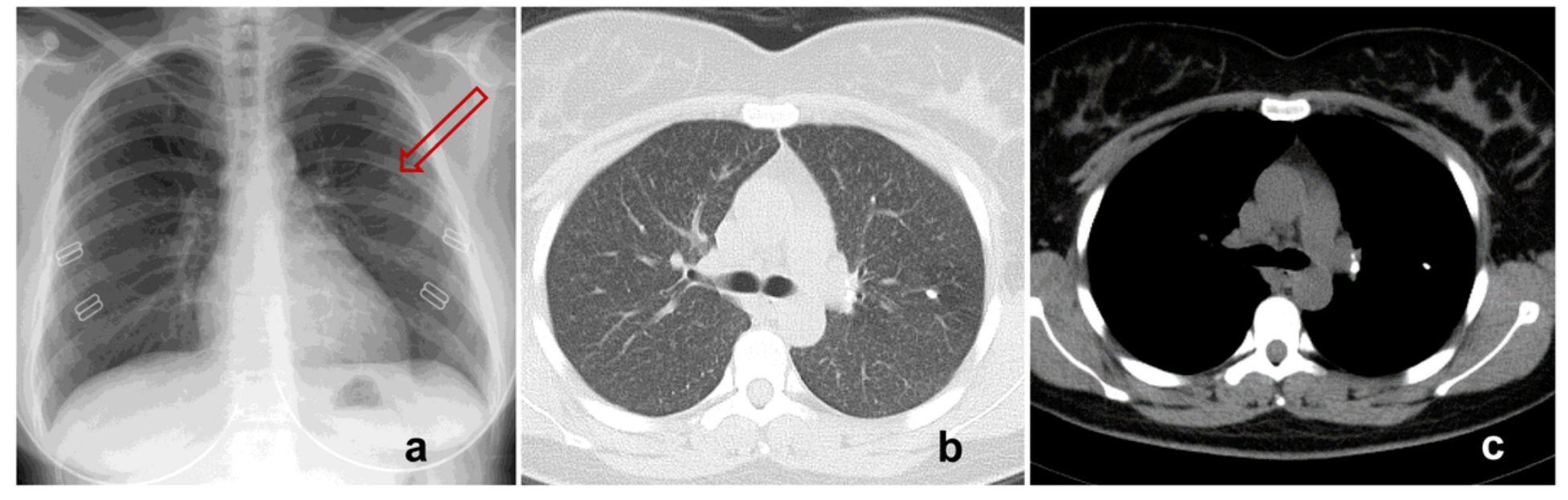

Figure 1

Chest imaging in a 32-year-old infertile woman. (a) Posteroanterior chest radiograph showing a scarring nodule in the left upper lobe (arrow) at screening before IVF-ET. (b) Chest computed tomography showing multiple miliary nodules of uniform density, size, and distribution. (c) A scarring nodule in the left upper lobe and calcification of the left hilar lymph nodes. IVF-ET, in vitro fertilization and embryo transfer 